\title{
Observations on some effects of L-triiodothyronine on carbohydrate and lipid metabolism in man $^{1}$
}

\author{
T. C. B. STAMP, J. W. H. DOAR, AND V. WYNN \\ From the Alexander Simpson Laboratory for Metabolic Research, \\ St Mary's Hospital Medical School, London
}

SYNOPSIS Fasting serum lipid levels and changes in plasma glucose, fatty acid non-esterified (Nefa and blood pyruvate levels during intravenous glucose tolerance tests were measured in 13 normail subjects before and one, five, and 15 days after the administration of 1-triiodothyronine (T3) calcusus lated as $6 \mu \mathrm{g} / \mathrm{kg}$ body weight.

Significant increases in the mean basal metabolic rate and the mean fasting plasma Nefa level occurred within 10 to 17 hours of a single dose of $\mathrm{T} 3$, while a rise in the mean fasting plasma glucose concentration just failed to achieve significance. Fasting concentrations of bloo pyruvate and serum triglyceride were unaffected. A significant fall in serum cholesterol levels was produced and lasted at least five days. All other indices returned to normal by five days.

During intravenous glucose tolerance tests performed at intervals after T3 administration nळ change in plasma glucose levels from control values was seen. Mean plasma Nefa and blood pyD ruvate levels, however, were significantly raised above control values during the early stages of the test 10 to 17 hours after T3. The relationship between these findings and those observed in clinica thyrotoxicosis is discussed.

While an association between hyperthyroidism and diabetes mellitus has long been recognized (Abt, 1962; Kreines, Jett, and Knowles, 1965), the underlying mechanism remains uncertain. Although large amounts of thyroid hormone may accelerate intravenous glucose uptake in experimental animals (Christophe, Mayer, and Jurjevics, 1960; Macho, 1960), there are no reports concerning possible similar effects in man.

Blood pyruvate levels may be raised in various states of impaired glucose tolerance, including thiamine deficiency (Buckle, 1967), diabetes mellitus (Fry and Butterfield, 1962), hyperthyroidism (Williams, Egana, Robinson, Asper, and Dutoit, 1943), Cushing's disease (Frawley, 1955), corticosteroid therapy (Frawley, 1955), oral contraceptive administration (Wynn and Doar, 1966), and obesity (Doar, Wynn, and Cramp, 1968). It is not known, however, whether levels may be raised following the administration of thyroid hormones.

Plasma non-esterified fatty acid (Nefa) levels are raised both in hyperthyroidism (Rich, Bierman, and Schwartz, 1959; Harlan, Laszlo, Bogdonoff, and Estes, 1963) and in normal subjects following the injection of large doses of 1-triiodothyronine (T3) ${ }^{1}$ This work was supported in part by contract no. Ph-43-67-1344 from the National Institutes of Health.

Received for publication 12 July 1968.
(Rich et al, 1959). The duration of activity and effect of smaller doses is not known. Although it has been suggested that raised plasma Nefa levels are fre quently if not invariably associated with impaired glucose tolerance (Randle, Hales, Garland, an\& Newsholme, 1963), it is not known whether this association may follow T3 administration.

We have investigated these problems in man by comparing levels of plasma glucose and Nefa and blood pyruvate in the fasting state and during intra옹 venous glucose tolerance tests before and at set intervals after the administration of a single dose oE T3.

While serum cholesterol and phospholipid levels are known to fall during administration of thyroids hormones (Danowski, 1962), there is little informa tion about serum triglyceride levels. We therefore investigated this problem by comparing fastingo levels of serum cholesterol and triglyceride before⿰ and after the administration of T3.

Changes in oxygen uptake were also determined in each subject as a further index of activity of the administered hormone.

\section{MATERIAL AND METHODS}

Thirteen healthy members of the medical and laboratory staff were studied, of whom seven were males and six 
were females, with ages ranging from 19 to 32 . All consumed their usual diet during the period of investigation.

Intravenous glucose tolerance tests were performed using a load of $0.5 \mathrm{~g}$ glucose $/ \mathrm{kg}$ body weight by methods previously described (Wynn and Doar, 1966). The glucose dose was kept constant for each individual during successive tests.

Fasting levels of plasma glucose, Nefa, and blood pyruvate are expressed as the mean of two determinations made at 15 -minute intervals immediately before glucose injection, and oxygen uptake was measured by a recording spirometer during this interval.

Control glucose tolerance tests were performed within 14 days of $\mathrm{T} 3$ administration, and further tests were then carried out on the first, fifth, and fifteenth days following administration.

Intravenous glucose tolerance curves were assessed in terms of $\mathrm{K}$ values. The half life $\left(t \frac{1}{2}\right)$ was obtained from a semi-logarithmic plot of the 20 to 60 -minute plasma glucose levels against time, and the $\mathrm{K}$ value obtained from the expression $K=\frac{69 \cdot 3}{t \frac{1}{2}}$

L-triiodothyronine (triiodothyronine sodium, Glaxo laboratories) was administered berween $6 \mathrm{pm}$ and $12 \mathrm{mid}$ night in a dose of $6 \mu \mathrm{g} / \mathrm{kg}$ body weight (dose range 300 to $460 \mu \mathrm{g}$ ). Five subjects received the hormone orally and eight subjects received an intravenous dose infused over 30 minutes. No differences relative to the route of administration were noted and results in the two groups were combined.

Plasma glucose levels were determined by a glucose oxidase method adapted for use with the AutoAnalyzer (Cramp, 1967), blood pyruvate by an automated enzymatic fluorimetric method (Cramp, 1968), plasma Nefa levels by the single extraction method of Dole and Meinertz (Dole and Meinertz, 1960), cholesterol by a modification of the method of Zlatkis, Zak, and Boyle (1953), and triglyceride by an automated fluorimetric method (Cramp and Robertson, 1969). Statistical analysis of the difference between paired data throughout was performed using Student's $t$ test.

\section{RESULTS}

No symptoms occurred after T3 had been given apart from questionable anxiety in two subjects and increased sweating in a third, on the first or second day.

Oxygen uptake expressed as a percentage of the basal metabolic rate (BMR) varied between $-14 \%$ and $+10 \%$ in control tests with a mean of $-2 \%$ (SD $\pm 6 \%$ ). On the first day after $\mathrm{T} 3$ administration the mean BMR rose by $5 \%(\mathrm{SD} \pm 5 \%, \mathrm{P}<0.02)$. No further measurements differed significantly from controls.

The mean control fasting levels of plasma glucose, Nefa, blood pyruvate, serum cholesterol, and triglyceride are compared in Table I with mean fasting values on the first, fifth, and 15 th days after T3 administration, together with the mean change from the original values. Figure 1 illustrates the mean levels of plasma glucose, Nefa, and blood pyruvate during intravenous glucose tolerance tests before and on the first and fifth days after the administration of T3.

Plasma glucose LeVels The mean change in fasting plasma glucose levels after T3 administration was $+5 \pm 9 \mathrm{mg} / 100 \mathrm{ml}^{1}$ on day $1,+4 \pm 11 \mathrm{mg} / 100$ $\mathrm{ml}$ on day 5 , and $+2 \pm 9 \mathrm{mg} / 100 \mathrm{ml}$ on day 15 . The increase on day 1 just failed to achieve statistical significance $(t=2 \cdot 18,0 \cdot 10>\mathrm{P}>0.05)$.

Control intravenous glucose tolerance tests yielded a mean $\mathrm{K}$ value of $1.96 \pm 0.75$ (range 1.41-3.92). No notable difference between glucose curves was seen after T3 administration (Fig. 1); thus the mean changes in $K$ value on days 1,5 , and 15 were $-0.15 \pm 0.81,-0.17 \pm 0.95$, and $-0.05 \pm 0.42$ respectively.

'Standard deviation of change.

TABLE I

MEAN FASTING LEVELS OF VARIOUS INDICES OF CARBOHYDRATE AND LIPID METABOLISM AND MEAN CHANGES AT VARIOUS INTERVALS AFTER T3 ADMINISTRATION

\begin{tabular}{|c|c|c|c|c|}
\hline & Control & Day 1 & Day 5 & Day $15^{2}$ \\
\hline $\begin{array}{l}\text { Plasma glucose }(\mathrm{mg} / 100 \mathrm{ml}) \\
\text { Mean change from controls }\end{array}$ & $87 \pm 8^{1}$ & $\begin{array}{l}92 \\
+5 \pm 9^{3}\end{array}$ & $\begin{array}{l}91 \\
+4 \\
+411\end{array}$ & $\begin{array}{l}89 \\
+2 \pm 9\end{array}$ \\
\hline $\begin{array}{l}\text { Plasma Nefa ( } \mu \text {-equiv/l) } \\
\text { Mean change from controls }\end{array}$ & $518 \pm 139$ & $\begin{array}{r}646 \\
+128 \pm 150\end{array}$ & $\begin{array}{l}472 \\
-46 \pm 110\end{array}$ & $\begin{array}{l}450 \\
-17 \pm 79\end{array}$ \\
\hline $\begin{array}{l}\text { Blood pyruvate }(\mathrm{mg} / 100 \mathrm{ml}) \\
\text { Mean change from controls }\end{array}$ & $0.58 \pm 0.18$ & $\begin{array}{r}0.59 \\
+0.01\end{array}$ & $\begin{array}{r}0.59 \\
+0.01\end{array}$ & $\begin{array}{r}0.61 \\
+0.03\end{array}$ \\
\hline $\begin{array}{l}\text { Serum cholesterol }(\mathrm{mg} / 100 \mathrm{ml}) \\
\text { Mean change from controls }\end{array}$ & $186 \pm 33$ & $\begin{array}{c}171 \\
-15\end{array}$ & $\begin{array}{l}160 \\
-26 \pm 16\end{array}$ & $\begin{array}{l}192 \\
+2\end{array}$ \\
\hline $\begin{array}{l}\text { Serum triglyceride }(\mathrm{mg} / 100 \mathrm{ml}) \\
\text { Mean change from controls }\end{array}$ & $66 \pm 37$ & $\begin{array}{l}71 \\
+5\end{array}$ & $\begin{array}{r}72 \\
+6\end{array}$ & $\begin{array}{r}70 \\
+4\end{array}$ \\
\hline
\end{tabular}

${ }^{1}$ Mean \pm standard deviation of control value.

'Nine subjects only.

${ }^{3}$ Mean \pm standard deviation of change from control value. 


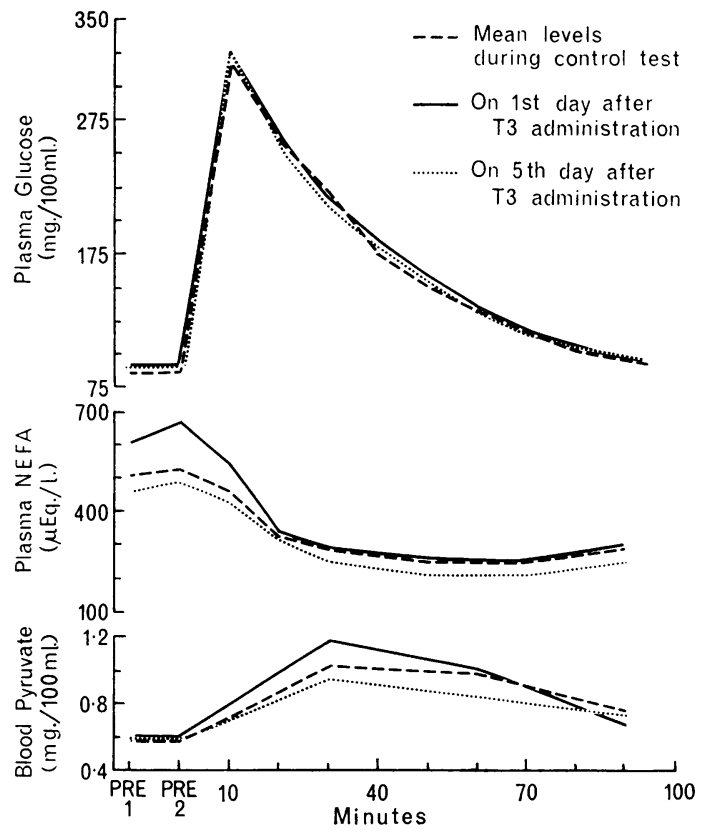

FIG. 1. Intravenous glucose tolerance tests.

PLASMA NEFA LEVELS The mean control fasting plasma Nefa level was $518 \pm 139 \mu$-equiv/l. Changes of $+128 \pm 150 \mu$-equiv/l. $(\mathrm{P}<0.01),-46 \pm$ $110 \mu$-equiv/l. (N.S.) ${ }^{1}$ and $-17 \pm 79 \mu$-equiv/l. (N.S.) occurred on days 1,5 , and 15 respectively. Mean plasma Nefa levels following glucose administration are shown in Figure 1. Apart from the difference in fasting levels only the change in the 10-minute value on day 1 differed significantly from control values $(P<0.01)$.

BLOOD PYRUVATE LEVELS The mean control fasting blood pyruvate level was $0.58 \pm 0.18 \mathrm{mg} / 100 \mathrm{ml}$. No significant change occurred following $\mathrm{T} 3$ administration. The mean values following glucose administration are shown in Figure 1. The mean increase in the 30-minute blood pyruvate level on day $1(+0 \cdot 13 \pm$ $0.18 \mathrm{mg} / 100 \mathrm{ml})$ was just significant $(P<0.05)$. The remaining points, however, did not differ significantly from control values.

SERUM LIPID LEVELS The control mean serum cholesterol level was $186 \pm 33 \mathrm{mg} / 100 \mathrm{ml}$. After T3 administration significant changes were found on day $1(-15 \pm 17 \mathrm{mg} / 100 \mathrm{ml}, \mathrm{P}<0.01)$ and on day 5 $(-26 \pm 16 \mathrm{mg} / 100 \mathrm{ml}, \mathrm{P}<0.001)$, this prolonged fall indicating a more sustained action of $\mathrm{T} 3$ on cholesterol levels than on plasma Nefa levels or

${ }^{1}$ Not significant.
BMR. The mean change on day 15 , however, was not significant $(+2 \pm 20 \mathrm{mg} / 100 \mathrm{ml})$. The mean fasting $\Rightarrow$ serum triglyceride level $(66 \pm 37 \mathrm{mg} / 100 \mathrm{ml})$ did not $\stackrel{5}{+}$ change significantly after $\mathrm{T} 3$.

\section{DISCUSSION}

While an association between hyperthyroidism and diabetes mellitus is well known the reported low incidence of clinical diabetes in hyperthyroidism of $3.2 \%$ (Abt, 1962) contrasts with an incidence of diabetic-type oral glucose tolerance tests of over $50 \%$ (Kreines et al, 1965), and it has been felt that theo former association is more apparent than real N (Butterfield and Whichelow, 1964). Factors whichi adversely influence the oral glucose tolerance test in $\vec{\omega}$ hyperthyroidism may include increased intestinal ${ }^{N}$ monosaccharide absorption (Althausen and Stock-으 holm, 1938), depletion of liver glycogen (Lamberg, $\vec{T}$ 1965), and inhibition of insulin release due to in-3 creased sympathetic tone or responsiveness (Porte, $\stackrel{\bar{\Omega}}{\triangle}$ Graber, Kuzuya, and Williams, 1966).

On the other hand, no consistent significant abnormalities have been found either during intra-.. venous glucose tolerance tests (Amatuzio, Schultz, Vanderbilt, Raines, and Nesbitt, 1954; Macho, 1958) or during slow constant intravenous glucose in-ㅡㅡㅇ fusions (Butterfield and Whichelow, 1964; Elrick, ֶ Hlad, and Arai, 1961). Experimental work in $\mathbb{\perp}$ animals, however, has shown increased intravenous $\vec{\overrightarrow{ }}$ glucose assimilation following thyroid treatment in rats (Christophe et al, 1960), rabbits (Macho, 1960), and eviscerated dogs (Rawson, Rall, and Sonenberg, 1955). Danowski, Bonessi, Sarver, and Moses (1964) were unable to demonstrate an effect of thyroid? feeding on the oral glucose tolerance test in man, and we have been unable to find published data on the effect of thyroid hormones on the intravenous glucose tolerance test in man.

Using a dose of T3 calculated to be large enough응 to produce detectable known metabolic changes $>$ (increased BMR, declining serum cholesterol levels, and raised fasting plasma Nefa levels) but smallN enough to avoid symptoms, we have been unable toshow any changes in intravenous glucose tolerance, the average curves before and at intervals after the $\omega$ administration of $\mathrm{T} 3$ being virtually identical.

The study was designed to uncover possibleo changes with time after T3 administration. The small rise in fasting plasma glucose observed following $\mathrm{T} 3 \stackrel{?}{+}$ administration did not achieve statistical significance. $\frac{T}{T}$ Significantly raised fasting plasma glucose levels have, however, been found in clinical hyperthyroid- $\varrho$

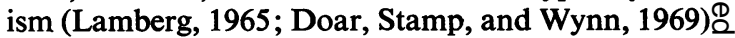
while experimental data in rats injected witho thyroxine have shown both hyperglycaemia (Chris- 
tophe $e t$ al, 1960) and a rise in liver glucose (Sternheimer, 1939).

Plasma Nefa levels are raised both in hyperthyroidism (Marks, Kiem, and Hills, 1960) and following T3 administration in large doses to control subjects (Rich et al, 1959), and the present study confirms this effect in the absence of hyperthyroid symptoms.

There have been few studies of blood pyruvate levels in thyrotoxicosis. Williams et al (1943) found raised blood pyruvate levels to be common both in the fasting state and following intravenous glucose administration. Using specific enzymatic methods, however, we have found the mean fasting blood pyruvate level to be normal in a group of 22 thyrotoxic subjects, though the rise following oral/intravenous glucose was abnormal (Doar et al, 1969). In the present series, although the mean fasting blood pyruvate level was unchanged after T3 administration, the mean 30-minute value after intravenous glucose was significantly raised on day 1 above the control value. Since the mean intravenous glucose curves were virtually identical, this suggests either impaired pyruvate degradation or increased pyruvate formation due to a greater proportion of the glucose load passing down the Embden-Meyerhof pathway to pyruvate rather than along alternative pathways, such as conversion to glycogen or the hexose monophosphate shunt. In line with the former hypothesis are the observations of Macho (1963), who found impaired pyruvate tolerance in thyroxine-treated rabbits.

The well-known action of thyroid hormones on serum cholesterol levels (Danowski, 1962) is confirmed by the present study, and the high degree of sensitivity and prolonged response to a single dose is worthy of note. This contrasts with the apparent absence of effect of T3 on triglyceride levels, a finding similarly observed in clinical hyperthyroidism (Doar et al, 1969).
T.C.B.S. gratefully acknowledges support by a fellowship from British Drug Houses Ltd.

We thank Mr D. G. Cramp and Miss G. Robertson for expert technical assistance.

\section{REFERENCES}

Abt, A. F. (1962). Metabolism, 11, 202.

Althausen, T. L., and Stockholm, M. (1938). Amer. J. Physiol., 123, 577.

Amatuzio, D. S., Schultz, A. L., Vanderbilt, M. J., Rames, E. C., and Nesbitt, S. (1954). J. clin. Invest., 33, 97.

Buckle, R. M. (1967). Proc. roy. Soc. Med., 60, 48.

Butterfield, W. J. H., and Whichelow, M. J. (1964). Metabolism, 13, 620.

Christophe, J., and Mayer, J. (1959). Endocrinology, 65, 475.

Cramp, D. G. (1967). J. clin. Path., 20, 910.

- (1968). Ibid., 21, 171.

- and Robertson, G. R. (1968). Analyt. Biochem., 25, 246.

Danowski, T. S. (1962). Clinical Endocrinology, Vol. II. Thyroid, p. 151 et seq. Williams and Wilkins, Baltimore.

- - Bonessi, J. V., Sarver, M. E., and Moses, C. (1964). Metabolism, $13,739$.

Doar, J. W. H., Stamp, T. C. B., and Wynn, V. (To be published). Wynn, V., and Cramp, D. G. (1968). Metabolism, 17, 690.

Dole, V. P., and Meinertz, H. (1960). J. biol. Chem., 235, 2595.

Elrick, H., Hlad, C. J., Jr, and Arai, Y. (1961). J. clin. Endocr., 21, 387

Frawley, T. F. (1955). Ann. N.Y. Acad. Sci., 61, 464.

Fry, I. K., and Butterfield, W. J. H. (1962). Lancet, 2, 66.

Harlan, W. R., Laszlo, J., Bogdonoff, M. D., and Estes, E. H., Jr (1963). J. clin. Endocr., 23, 33.

Kreines, K., Jett, M., and Knowles, H. C., Jr (1965). Diabetes, 14, 740.

Lamberg, B. A. (1965). Acta med. scand., 178, 351.

Macho, L. (1958). Ibid., 160, 485.

(1960). Acrh. int. Physiol, 68, 713

and Palkovic, M. (1963), Ibid., 71, 758.

Marks, B. H., Kiem, I., and Hills, A. G. (1960). Metabolism, 9, 1133.

Porte D., Jr, Graber, A. L., Kuzuya, T., and Williams, R. H. (1966). J. clin. Invest., 45, 228.

Randle, P. J., Garland, P. B., Hales, C. N., and Newsholme, E. A. (1963). Lancet, 1, 785.

Rawson, R. W., Rall, J. E., and Sonenberg, M. (1955). In The Hormones, edited by G. Pineus and K. V. Thimann, Vol. III, p. 433. Academic Press, New York.

Rich, C., Bierman, E. L., and Schwartz, I. L. (1959). J. clin. Invest., $38,275$.

Sternheimer, R. (1939). Endocrinology, 25, 899.

Williams, R. H., Egana, E., Robinson, P., Asper, S. P., and Dutoit, C. (1943). Arch. intern. Med., 72, 353.

Wynn, V., and Doar, J. W. H. (1966). Lancet, 2, 715.

Zlatkis, A., Zak, B., and Boyle, A. J. (1953). J. Lab. clin, Med., 41, 486. 